\title{
Sediment management and the renewability of floodplain clay for structural ceramics
}

\author{
Michiel J. van der Meulen • Ane P. Wiersma • \\ Marcel van der Perk • Hans Middelkoop • Noortje Hobo
}

Received: 13 March 2009 / Accepted: 12 June 2009/Published online: 16 July 2009

(C) The Author(s) 2009. This article is published with open access at Springerlink.com

\begin{abstract}
Background, aim, and scope The Netherlands has vast resources of clay that are exploited for the fabrication of structural ceramic products such as bricks and roof tiles. Most clay is extracted from the so-called embanked floodplains along the rivers Rhine and Meuse, areas that are flooded during high-discharge conditions. Riverside clay extraction is - at least in theory-compensated by deposition. Based on a sediment balance (deposition versus extraction), we explore the extent to which clay can be regarded as a renewable resource, with potential for sustainable use. Beyond that, we discuss the implications for river and sediment management, especially for the large engineering works that are to be undertaken to increase the discharge capacities of the Rhine and Meuse.

Materials and methods Extraction rates are based on production statistics for clay, as well as those for fired end-products. Deposition rates are estimated from published and unpublished geological data (clay volumes and
\end{abstract}

Responsible editor: Philip N. Owens

M. J. van der Meulen $(\bowtie) \cdot$ A. P. Wiersma

Deltares,

P.O. Box 85467, 3508 AL Utrecht, Netherlands

e-mail: michiel.vandermeulen@deltares.nl

M. J. van der Meulen · A. P. Wiersma

TNO - Geological Survey of the Netherlands,

P.O. Box 80015, 3508 TA Utrecht, Netherlands

M. van der Perk $\cdot$ H. Middelkoop $\cdot$ N. Hobo

Department of Physical Geography, Faculty of Geosciences,

Utrecht University,

P.O. Box 80115, 3508 TC Utrecht, Netherlands

N. Hobo

Alterra, Wageningen University and Research Centre,

P.O. Box 47, 6700 AA Wageningen, Netherlands thicknesses, datings, etc.) and from morphological modeling studies. Comparisons between extraction and deposition are made at three different time-space scales: (1) long term (post-1850)/large scale (all Dutch floodplains), (2) present/ large scale, and (3) present/site scale. The year 1850 is relevant because it approximately marks the beginning of the current, fully engineered river systems, in which depositional processes are constrained by dikes and groynes. As the Industrial Revolution began in the same period, post- 1850 sediments can be identified by their pollution with heavy metals.

Results (1) We estimate the post-1850 clay volume in situ at about $0.20 \mathrm{~km}^{3}$, and the total extracted volume in the same period at about $0.17 \mathrm{~km}^{3}$. This puts the net long-term average deposition rate of clay at $\sim 1.3$ million $\mathrm{m}^{3} /$ year and the corresponding extraction rate at $\sim 1.1$ million $\mathrm{m}^{3} /$ year. (2) Current accumulation is approximately 0.4 million $\mathrm{m}^{3 /}$ year and expected to increase, and current extraction is about 0.7 million $\mathrm{m}^{3} / \mathrm{year}$ and expected to decrease. (3) Clay extraction creates a depression that has an increased sediment-trapping efficiency. This local effect is not considered explicitly in large-scale morphological modeling. Based on maximum observed sedimentation rates, we estimate that replenishment of a clay site takes in the order of 150 years. As clay extraction lowers some $0.5 \mathrm{~km}^{2}$ of floodplain yearly, a surface area of approximately $75 \mathrm{~km}^{2}$ would be required for sustainable clay extraction. This is about $1 / 6$ of the total surface area of the embanked floodplains.

Discussion On the long term, clay extraction from the embanked floodplain depositional environment has been sustainable. At strongly decreasing deposition rates, the ratio between extraction and replenishment seems to have shifted towards unsustainable. However, current sedimentation is estimated conservatively. The site-scale approach 
suggests that, even if extraction would currently exceed deposition, this could be resolved with sediment management, that is, with site restoration measures aimed at higher sediment-trapping efficiency. Our results have implications for river engineering, especially where substantial digging is involved (floodplain lowering, high-discharge bypass channels, obstacle removal). First, this inevitably affects the clay resources that we studied, while resource sterilization should be avoided. Secondly, the effect that any form of digging has on subsequent sedimentation-increased rates - relates to long-term river maintenance.

Conclusions, recommendations, and perspectives We conclude that floodplain clay is a renewable resource, especially if managed accordingly. Beyond that, we established that clay extraction is a significant, lasting factor in floodplain evolution along the Rhine and Meuse Rivers. The interests of the extractive industry and river managers could be served jointly with sediment management plans that are based on sediment-budget analyses.

Keywords Building raw materials · Clay · Netherlands · Renewable resources $\cdot$ Sediment management $\cdot$ Structural ceramics industry $\cdot$ Sustainable resource management

\section{Background, aim, and scope}

The Netherlands has vast resources of clay that are exploited for earthworks and fabrication of structural ceramic products such as bricks and roof tiles (van der Meulen et al. 2007a, b; Fig. 1). As water tables are generally shallow, most Dutch clay extractions are landsurface lowerings of about $1.5 \mathrm{~m}$, with a surface area of a few hectares, the majority of which are located in the embanked floodplains of the rivers Rhine and Meuse. Such excavations are relatively easy to restore and, following an agreement in the early 1990s between the Royal Dutch Association of Brick Producers (KNB) and World Wildlife Fund for Nature, Dutch Branch (WWF-Netherlands), riverside clay extraction became consistently coupled with nature development (Helmer et al. 1992; Fig. 2). In this respect, the extraction of clay compares favorably with that of most other minerals worked in the Netherlands.

Apart from the site restoration possibilities, riverside clay extraction stands out because it is undertaken in an environment where the resource is actively deposited, and exploitation is compensated by replenishment - at least in theory. The purpose of the present paper is to explore the extent to which clay can be regarded as a renewable resource, with potential for sustainable use (sensu Brundtland 1987; for discussions on sustainable mineral development, see Wagner et al. 2004; van der Meulen 2005). In the strictest definition, renewable resources are either biotic or fluxes (wind, hydropower, solar energy, etc.). In a broader sense, however, it refers to any resource that can be used without depleting its stocks, and this definition includes sediments. Unlike quarries or aggregate pits, riverside clay excavations dating back to the 1950 s or earlier are known to have been replenished by overbank deposition, and they are now ready for a second round of extraction (Sigmond et al. 2001). This indicates that exploitation of clay resources can be sustainable, provided that the overall rate of consumption and deposition is more or less in balance.

In this paper, we compare the deposition and exploitation of clay resources (sediment budgeting). Beyond that, we address the extent to which humans determine sedimentary processes at a fairly large scale, which, in its turn, translates to river and sediment management options for the Dutch Rhine and Meuse. We do not intend to present an in-depth analysis of Dutch embanked floodplains as depositional environment: we present first-order system characteristics based on a review of largely existing data.

\section{Concepts}

\subsection{Renewability and clay deposition}

Consumptive use of renewable resources is considered to be sustainable if it does not exceed replenishment. In the context of the present paper, we define replenishment as sedimentation of clay (1) deposited in a setting that allows for (later) extraction and (2) of (potentially) fireable quality (Table 1). These criteria exclude subaqueous clay occurrences, as clay is invariably extracted using dry techniques: it is excavated, not dredged. They also exclude clays deposited in (supra)tidal marshes or other coastal settings because of the likelihood of deleterious impurities such as shell fragments or particulate organic matter (van der Meulen et al. 2007b).

We therefore approximate replenishment with an estimate of clay accumulation in the only significant, active terrestrial depositional environment in the Netherlands, i.e., the aforementioned embanked floodplains. The remaining portion of the Dutch lowlands, where some $60 \mathrm{~km}^{3}$ of clay was deposited during the Holocene, has become almost completely sediment-starved as a result of diking (van der Meulen et al. 2007c). We disregard clay deposition along brooks, etc.

The present study focuses on clay extraction for structural ceramics. It may seem arbitrary to exclude clay for other purposes from our analysis, i.e., for earthwork such as dike building or landfill covering. However, other than being displaced and shaped, clay is neither altered for such applications, nor is it really removed from its depositional environment. Consequently, we do not consid- 
Fig. 1 Occurrences of clay in the Netherlands that are extractable, i.e., having (1) a thickness $\geq 1 \mathrm{~m}$ without intercalations and (2) $<25 \%$ chance of encountering particulate organic material or shells. For details of the underlying resource assessment, see Van der Meulen et al. (2005, 2007b). $K N B$, the Royal Dutch Association of Brick Producers, represents the larger part of Dutch structural ceramics industry; $N B$ plotted are brick production sites, not (necessarily) clay extraction sites

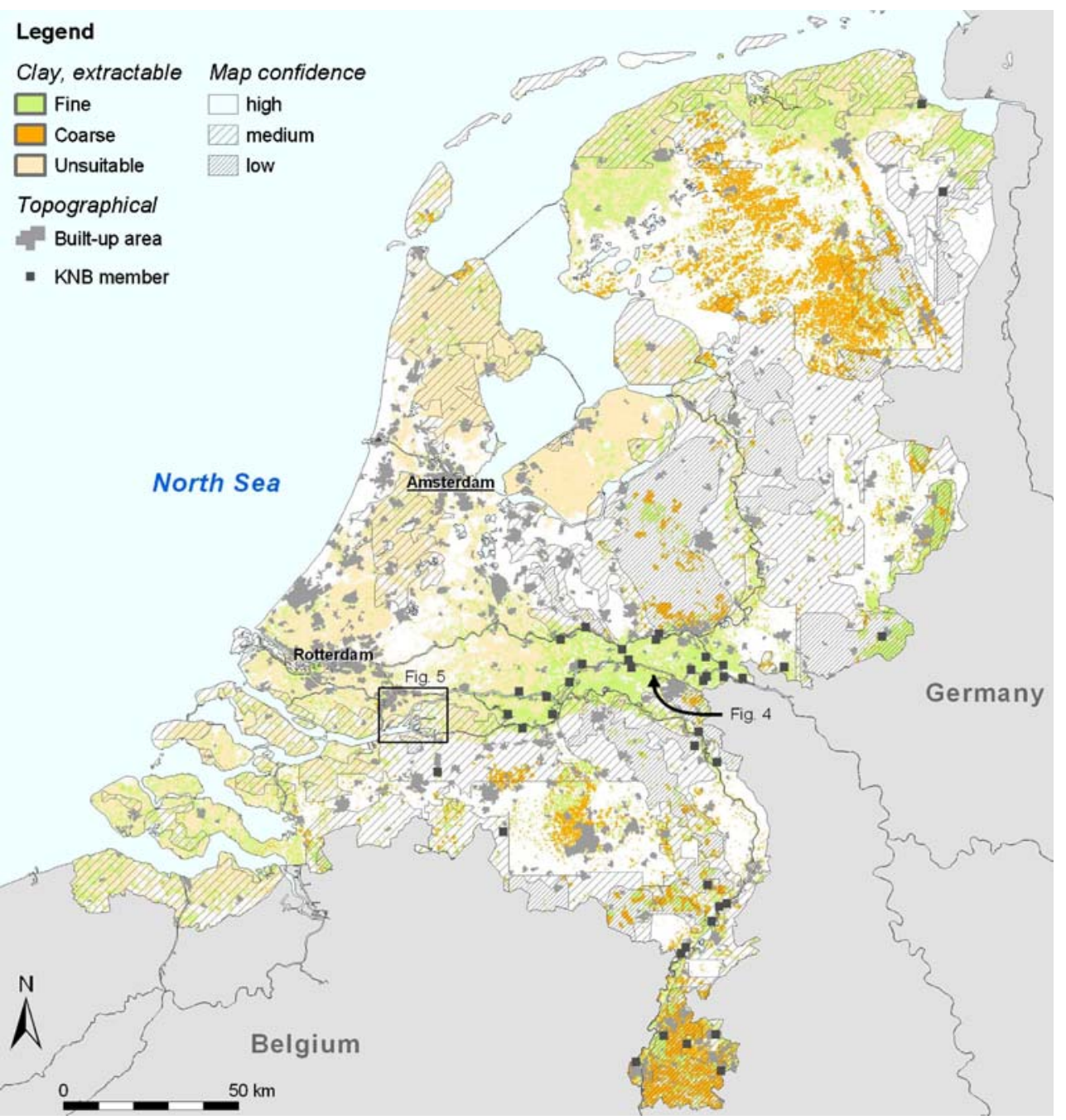

er this a matter of consumptive clay use and, hence, nor of resource depletion in the above sense.

\subsection{Embanked floodplains: depositional system and processes}

At present, Dutch rivers are confined to such an extent that they can hardly be considered rivers in the strict sense, i.e., hydraulically or sedimentologically (Figs. 3 and 4). The socalled winter dikes act as system boundaries: these are high dikes (up to $\sim 5 \mathrm{~m}$ above the floodplain surface), placed at some distance from the river channel (up to $\sim 500 \mathrm{~m}$ ), in order to protect the coastal and fluvial lowlands against flooding during peak-discharge and/or storm-surge conditions. Embanked floodplains, i.e., the areas between the winter dike and the river channel, are flooded occasionally, typically between the late autumn and early spring. The socalled summer dikes, low dikes or strengthened natural levees that border the river channel, prevent the embanked floodplains from being flooded during summer (i.e., minor peak flow) conditions. Other than summer dikes, the river channel is fixated with groynes that concentrate flow in order to maintain channel depth for navigability. At few places, the riverbed is armored with concrete or armorstone.

Embanked floodplains are mostly pastures (see Fig. 4), a function that is compatible with occasional flooding during the winter season. In some areas, nature has been created (e.g., after clay extraction). Several brick and roof tile plants are present, built on flood-free mounds. Structural ceramics manufacture, including clay extraction, is the main industrial activity that takes place there. Some nineteenth century plants have protected heritage status.

Winter dikes were constructed between approximately 1000 and 1350 AD (Middelkoop 1997; Hesselink 2002). Groyne construction and river-bed armoring took place in the mid-nineteenth century, and during this operation ("river normalization"), meander bends were straightened as well. This suite of hydraulic-engineering measures is reflected in the depositional sequence of the embanked floodplains.

Prior to fixation, the river channel (or channels) migrated laterally within the confinement of the winter dikes, and 


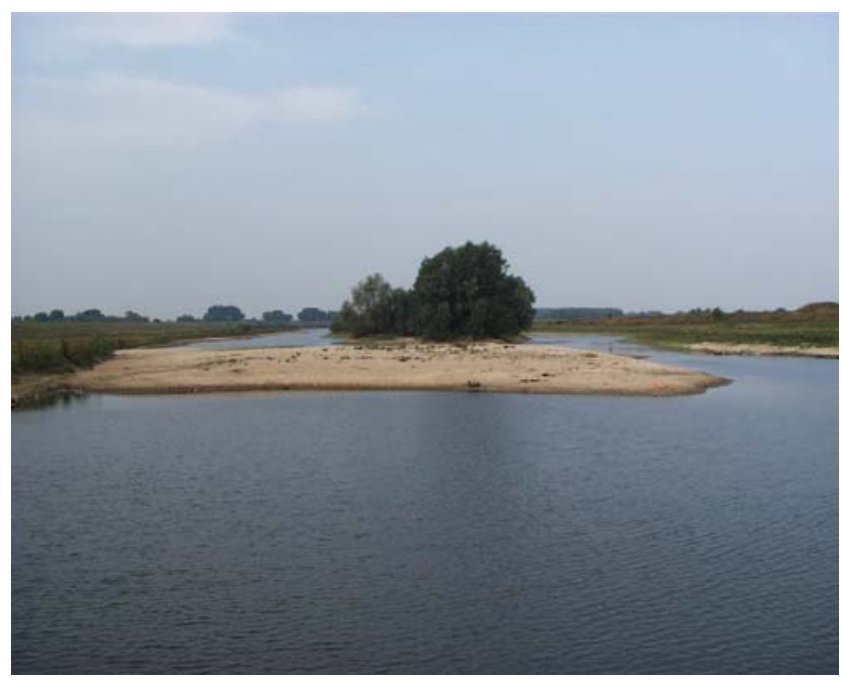

Fig. 2 A restored clay site along the river Waal. Extraction and landscaping are aimed at recreating the surface on which clay deposition took place, in this case the top of the underlying sandy channel deposits. In this way, a natural morphology is mimicked, which fits the amenity of this particular environment

sand and clay were both deposited and eroded throughout what later became embanked floodplains. After fixation in the nineteenth century, sand transport and sedimentation became almost exclusively limited to the river bed, typically in the form of migrating ripples and dunes. Only at high discharge, sand may be also washed onto the embanked floodplains, forming small natural levees on the channel banks. Clay and silt are carried in suspension and deposited on the embanked floodplains during and immediately after discharge peaks. Summer dikes prevent flooding (and sedimentation) up to certain discharge levels, but when overtopped, they are basically a sediment trap that retain floodwater with its sediment load. More importantly, river normalization raised the preservation potential of embanked floodplain clays because it puts an end to erosion of floodplain deposits by migrating channels. At present, a typical profile in the embanked floodplains consists of a clay layer of up to about $2 \mathrm{~m}$ in thickness, on top of sandy channel/point-bar deposits. This suite is obviously disturbed if aggregates or clay extraction has taken place.

The above depositional system description pertains to the Rhine and Meuse distributaries in the central Dutch fluvial plains, where most superficial clay extraction takes place. The situation along the upstream Meuse is different in the sense that the river is confined by the terraced flanks of an incised valley rather than by winter dikes. It is similar in having summer dikes, and the process of fines deposition behind these dikes is basically the same, even though the depositional surface is not a floodplain sensu stricto.

\section{Materials and methods}

\subsection{Study area delimitation}

We delimited our study area using the official positions of the state waters (which include the rivers Rhine and Meuse) and those of the primary flood defense systems (which includes the winter dikes). The combination of AHN, a high-density laser altimetry grid of the Netherlands, and satellite imagery allowed us (1) to verify and fine-tune the floodplain delimitations, (2) to exclude built-up/flood-free areas, and (3) if relevant, to exclude areas that seem morphologically or otherwise unsuitable for the deposition of clay with the desired quality. The most important exclusions occur in the Biesbosch, a semi-natural wetland area located at the apex of Hollands Diep, one of the Rhine-Meuse estuaries (Fig. 5). The morphology of the Biesbosch, with creek-like channels cutting through forested and reed-covered wetlands, resembles estuarine tidal flats, but estuary closure (the Delta Works) caused the former brackish mesotidal regime to shift to freshwater micro/non-tidal in 1970. In the absence of embankments and due to the vegetation, we do not expect clay of potential fireable quality to be deposited in this swampy area. All geographical information and altimetry data were courtesy of the Ministry of Transport, Public Works and Water Management.

Table 1 Approximate requirements for clay in the structural ceramics industry and for dike maintenance (for comparison)

\begin{tabular}{|c|c|c|c|c|c|c|c|}
\hline \multirow[t]{2}{*}{ Application } & \multicolumn{5}{|c|}{ Share of grain-size fraction $(\%)$} & \multirow[t]{2}{*}{ C-org (\%) } & \multirow[t]{2}{*}{$\mathrm{CaCO}_{3}(\%)$} \\
\hline & $<2 \mu \mathrm{m}$ & $<10 \mu \mathrm{m}$ & $63-250 \mu \mathrm{m}$ & $\geq 250 \mu \mathrm{m}$ & Sand & & \\
\hline Roof tiles & & $50-57$ & $<20$ & $<40$ & & $<3$ & $<25$ \\
\hline Bricks & & $40-42$ & $<20$ & $<40$ & & $<3$ & $<25$ \\
\hline Extruded products & & $40-55$ & $<20$ & $<40$ & & $<3$ & $<25$ \\
\hline Dike maintenance & $18-40$ & & & & $<40$ & $<3$ & \\
\hline
\end{tabular}

All shares (percent) are given as mass percentages. Note that clay in the industrial definition may include lithologies that geologist would classify as loam or silt. Modified from Van der Zwan (1990) 


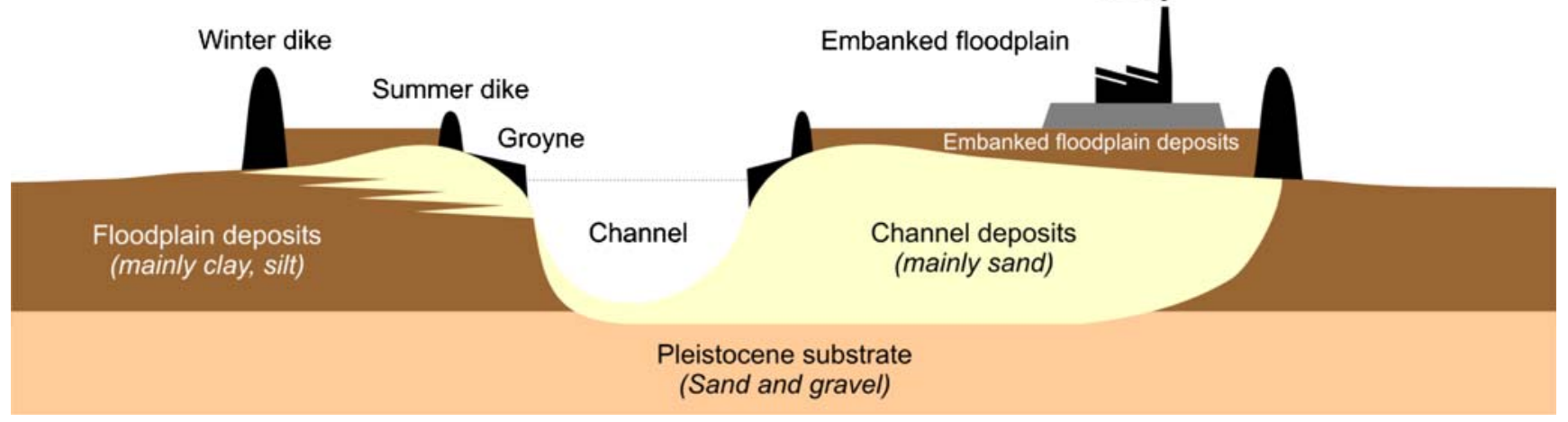

Fig. 3 Schematic cross section representing the embanked-floodplain depositional environment

\subsection{Sediment-budgeting approach}

We estimated and compared volumes of clay consumption at three different time-space scales (long term/large scale, present/large scale and present/site scale).

Long term/large scale Superficial clay occurrence in the embanked floodplains was assessed using a 3D clay resource model presented by van der Meulen et al. (2007b, see also van der Meulen et al. 2005). This geocellular model was obtained by a 3D interpolation of lithological composition (i.e., shares of clay, sand, gravel, etc.) and deleterious impurities such as shell fragments and organic debris, using about 380,000 borehole descriptions. Model raster dimensions are $250 \times 250 \times 0.2 \mathrm{~m}$ down to $3 \mathrm{~m}$ below the surface, and $250 \times 250 \times 1 \mathrm{~m}$ below that level. Using the criteria such as maximum overburden and intercalation thickness, technically exploitable clay volumes were identified by analyses of vertical model cell stacks. We clipped the results to the embanked floodplains in order to arrive at an estimate of the total exploitable clay resource volume in the study area. In order to be sure that no clay is included that has been removed, we clipped out the model below standing bodies of water in the floodplains (aggregates pits, etc.). Superficial clay can be assumed to have been removed at such places; this clipping step was taken to disregard data that predate extraction or earth removal. We then used new and published datings of clay deposits that allow an assessment of embanked floodplain accumulation rates over longer timescales (decadal to century scale) using heavy metal and radionuclide $\left({ }^{137} \mathrm{Cs}\right)$ distributions in soil profiles (see Middelkoop 2000; van den Berg and van Wijngaarden 2000).

Fig. 4 Aerial photograph of the Winssense Waard, an embanked floodplain along the Waal distributary of the Rhine (see Fig. 1 for location)

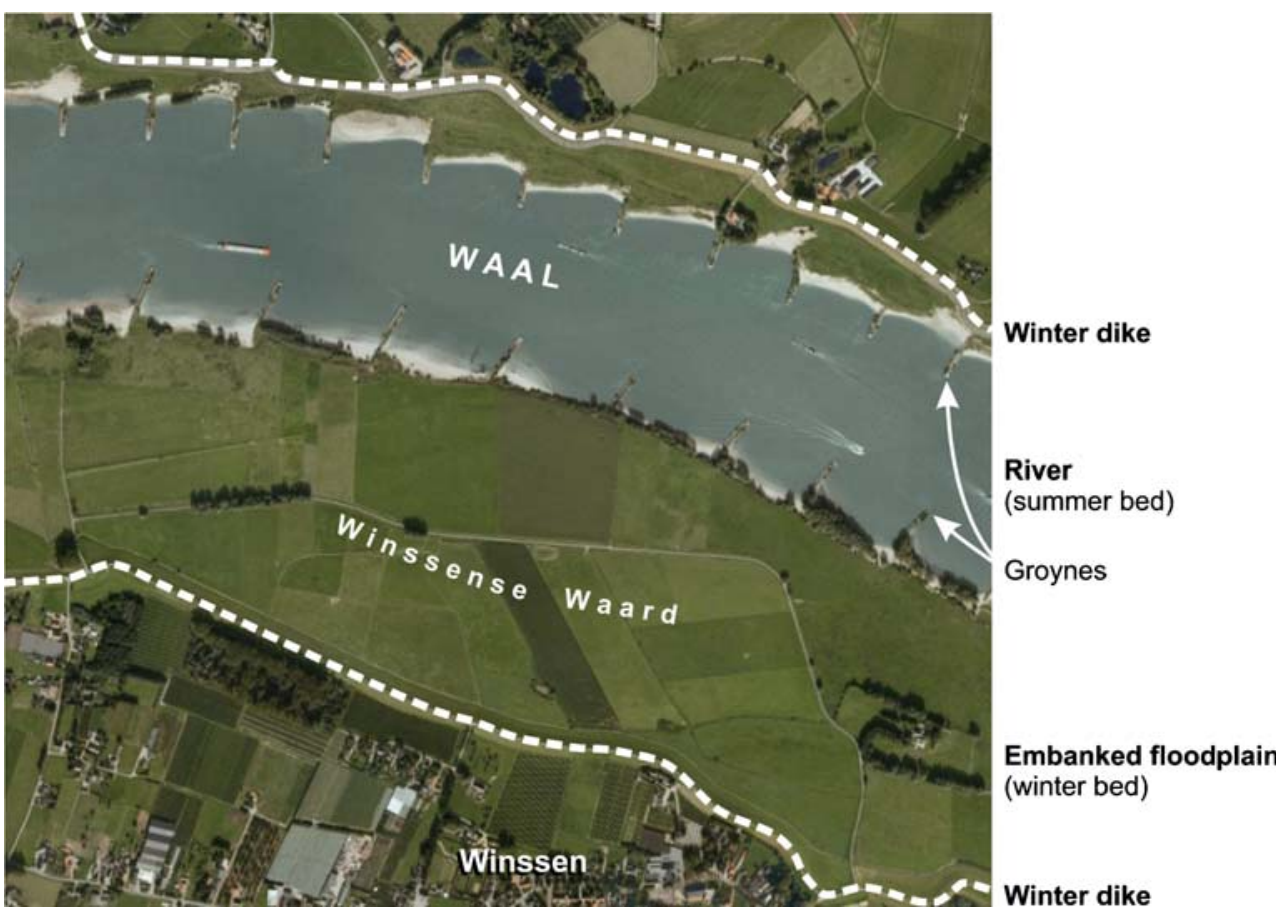


Fig. 5 Aerial photograph of the Biesbosch. Canopied areas delimited by hashed white lines have been excluded from our study area (see text for explanation and Fig. 1 for location)

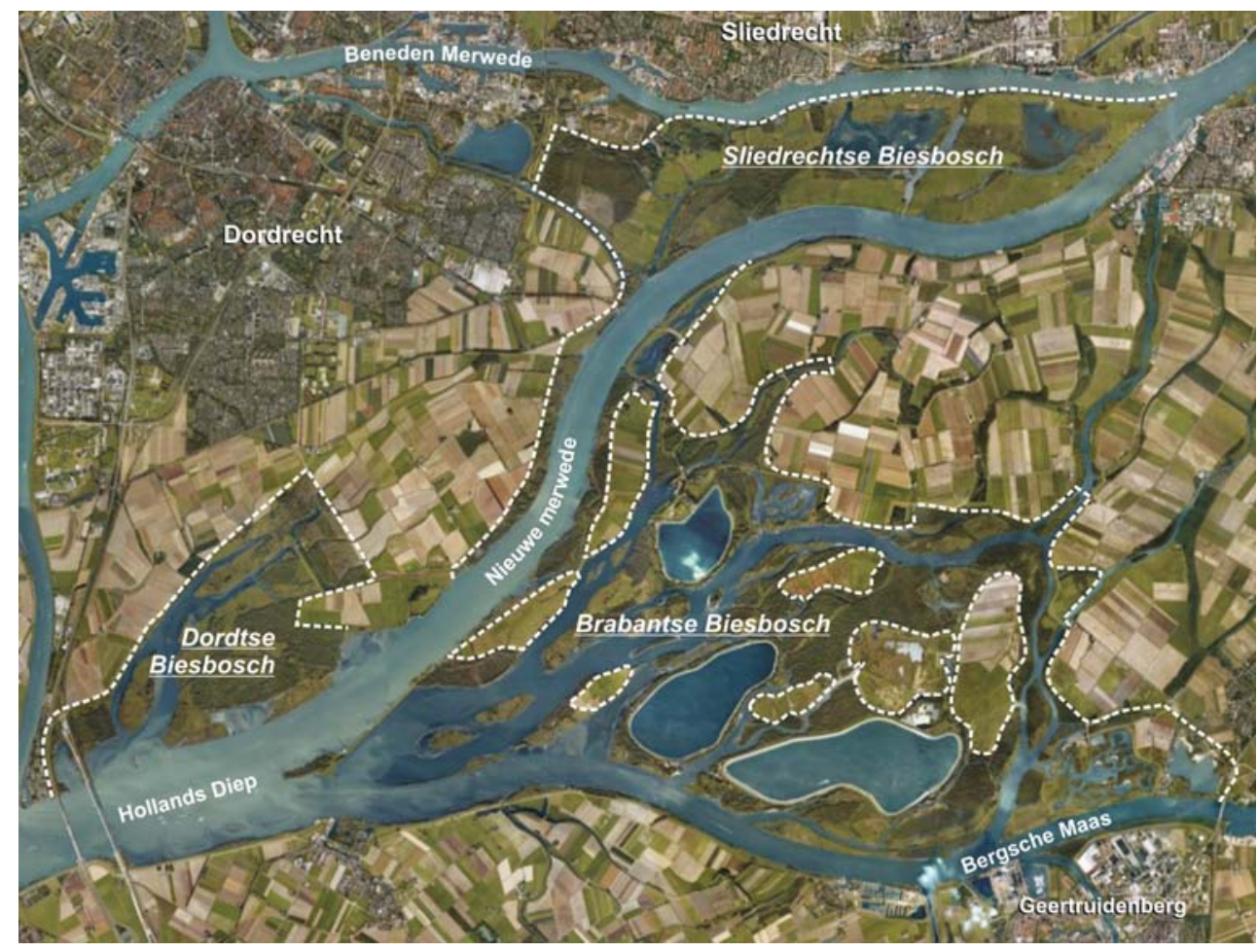

Extracted amounts of clay are calculated or estimated from clay production statistics, gathered and published by the Dutch mineral-planning authorities, i.e., the Ministry of Transport, Public Works and Water Management (The Hague) for extraction in the so-called State Waters, and the Provinces in all other cases (see van der Meulen et al. 2007a for an overview). We also used brick and roof tile production statistics, gathered and published by Statistics Netherlands (Statline 2008).

Present/large scale The above approach has the advantage of robustness, as it is based on the entire clay volume in the embanked floodplains. However, it lacks precise time control and it reflects deposition processes and extraction practices that are not representative of the current situation. More specifically, sedimentation rates dropped due to increasing floodplain elevations and associated decreasing flooding frequencies (Middelkoop 1997), and the long-term average clay accumulation rate based on the entire clay volume is therefore an overestimation of current accumulation. A second-order approach to the evaluation of sustainable clay extraction is based on the comparison of current extraction and sedimentation.

For the main distributaries of the Rhine, we used estimates of contemporary sedimentation rates and patterns from model calculations (van der Perk et al. 2008; Straatsma et al. 2009). The model consists of a hydrodynamic component (WAQUA) that simulates the twodimensional water-flow patterns, and a sedimentation component (SEDIFLUX) that simulates sediment transport and deposition (Middelkoop and van der Perk 1998). Along the Rhine, the discharge-frequency distribution for 1901 to 2000 was used in combination with a sediment rating curve from 1970 to 2006 . Model parameter values for sedimentsettling velocity $\left(6.7 \times 10^{-5} \mathrm{~m} / \mathrm{s}\right)$ and critical bed-shear stress for sedimentation $\left(2.0 \mathrm{~N} / \mathrm{m}^{2}\right)$ were assigned based on previous modeling studies (Middelkoop and van der Perk 1998; Thonon et al. 2005). In our analysis, we only took into account floodplains delimited as described above, and we excluded grid cells where erosion is likely to take place, i.e., cells where the critical bed-shear stress is exceeded more than once a year (e.g., on the river side of the summer dikes). The simulated sedimentation rates in kilogram per square meter per year were converted to millimeter per year, assuming a dry bulk density of the sediment of $1,600 \mathrm{~kg} / \mathrm{m}^{3}$. We verified and supplemented modeling results with sedimentation measurements, obtained using sediment traps (Middelkoop and Asselman 1998; Thonon et al. 2007). For the River Meuse, no SEDIFLUX-modeling studies have been performed, and therefore, we upscaled the accumulation rates measured in three representative embanked floodplains from one major flood event derived from sediment traps (Middelkoop and Asselman 1998) into yearly average values by using flood-frequency statistics.

In the present/large-scale approach, we included deposition in water bodies that occur in the embanked floodplains. These include aggregate pits that, strictly spoken, do not meet the area delimitation criteria discussed in Section 3.1 because clay deposited at such depths (e.g., $20 \mathrm{~m}$ ) cannot be considered a (future) clay resource. However, we could 
not systematically distinguish between such deep pits and shallow water or periodically inundated former clay sites. Clay deposited in the latter setting can in principle be excavated (rather than dredged) and would at least technically qualify as clay resource. The resource quality issues associated with such choices is discussed in Section 5.3.

Present/site scale The above two approaches result in approximations of the sediment-trapping efficiency of the embanked floodplain depositional system as a whole, on two time scales. While this provides insight in the main system characteristics, including the overall impact of clay extraction, both methods are insufficiently tuned to extraction as such. Extraction in the floodplains is basically a local perturbation of the depositional system, in the sense that a depression is created that potentially increases the local sediment-trapping efficiency. However, clay extraction is neither represented in sedimentation modeling, nor has it been taken into account explicitly when calculating floodplain sedimentation rates from measured data.

In a third order approach, we explore replenishment of individual clay extraction sites. If, for example, the flooding frequency of a site increases proportionally to surface level lowering, then we expect sedimentation to attain (or exceed) the late nineteenth century rates, or the high levels that are currently observed in depressions in the embanked floodplains. This applies especially when landscaping of a clay extraction site would be geared towards sediment trapping. This requires capturing and retaining sediment-bearing (flood) water which could, for example, be achieved with an open connection to the river at high discharge and/or semienclosure by a low quay. Without elaborating on the viability or technicalities of such measures, we explore the effect of locally increased sediment-trapping efficiency associated with clay extraction, assuming that sedimentation can be raised to the highest observed rates, current or historical.

Heavy metal and radionuclide $\left({ }^{137} \mathrm{Cs}\right)$ distributions in soil profiles allow an assessment of the decadal-scale variation in floodplain sedimentation from around 1850 to present (Middelkoop 2000; van den Berg and van Wijngaarden 2000). The maximum attainable rates were used to estimate the rate at which a clay site is or can be refilled. We used SEDIFLUX-modeled maxima for comparison.

\section{Results}

\subsection{Long term/large scale}

The total surface area of the embanked floodplains is 490.5 and $454.3 \mathrm{~km}^{2}$ when excluding bodies of standing water.
The total exploitable clay volume, obtained from the clay resource model, is estimated at $0.615 \mathrm{~km}^{3}$ (Fig. 6). The average clay thickness of $1.35 \mathrm{~m}$ is in good accordance with the generic layout of the floodplain deposits described above. The aforementioned process of river normalization around 1850, i.e., the shift towards the present constrained depositional setting, coincided with the onset of the Industrial Revolution, which had a significant impact on water quality in the Rhine and Meuse catchments. Industrialization is reflected in floodplain deposits as high heavy metal concentrations $(\mathrm{Pb}, \mathrm{Zn}, \mathrm{Cu}$, and $\mathrm{Cd})$. Chemical analyses enabled Middelkoop $(1997,2000)$ to distinguish between pre- and post-normalization overbank deposits (non-polluted and polluted sediments, respectively). Based on the depth over which increased metal concentrations occur in floodplain profiles from several sites, we attribute one third of the floodplain clays, i.e., $0.2 \mathrm{~km}^{3}$, to post- 1850 . This puts the average net accumulation rate from 1850 to present at 1.3 million $\mathrm{m}^{3} /$ year, and the net pre- 1850 rate $\left(0.41 \mathrm{~km}^{3}\right.$ in 500 to 850 years) at 0.5 to 0.8 million $\mathrm{m}^{3} /$ year.

Just as the pre-1850 clay volume is determined by deposition and erosion, net post-1850 accumulation is the sum of deposition and extraction. In the absence of proper statistics, however, the latter factor can only be approximated. As reliable clay production figures date back to 1980 only, we estimate the order of magnitude using production statistics of bricks and roof tiles, which are available for 1938 to 1991 (Statline 2008). For this purpose (Fig. 7), we added (1) the cumulative brick volume (104× $10^{9}$ pieces, reportedly of the standard "Waal Formaat" size of $20 \times 7 \times 5 \mathrm{~cm}$ ) and (2) the cumulative roof tiles volume $\left(3.69 \times 10^{9}\right.$ pieces, at an assumed standard weight of $3 \mathrm{~kg}$ and a density of $1,700 \mathrm{~kg} / \mathrm{m}^{3}$ ). A comparison of the volume thus obtained with clay extraction statistics between 1980 and 1991 shows that consumption-based figures are underestimations of between $51 \%$ and $69 \%$. An average coverage of $60 \%$ is used to arrive at extraction estimates from 1937 until 1979, yielding a total of 148 million $\mathrm{m}^{3}$.

We obtained an estimate for the production from 1850 to 1936 assuming proportionality between clay extraction and economic growth (gross domestic product-GDP). From the 1950 s till the early 1970 s, clay production increased by about 2\%/year, while GDP grew by 5.07\%/year (van Zanden 1997). Applying this ratio to GDP growth for 1850 to 1937 (van Zanden 1997), we estimate an overall clay production increase from 0.8 to about 2 million $\mathrm{m}^{3 /}$ year for this period, at an average increment of about $1 \%$ / year. Adding the cumulative annual totals for 1850 to 1937 to post-1938 production gives a crude estimate of 260 million $\mathrm{m}^{3}$ of clay from 1850 to date. Sigmond et al. (2001) established that about two thirds of Dutch clay extraction takes place in the embanked floodplains. In the absence of a better figure, and after discussion with industry representa- 
Fig. 6 Clay thickness in the embanked floodplains along the Rhine branches (names indicated) and the lower Meuse, and on the lowest terraces of the upstream Meuse (modified from Van der Meulen et al. 2007b)

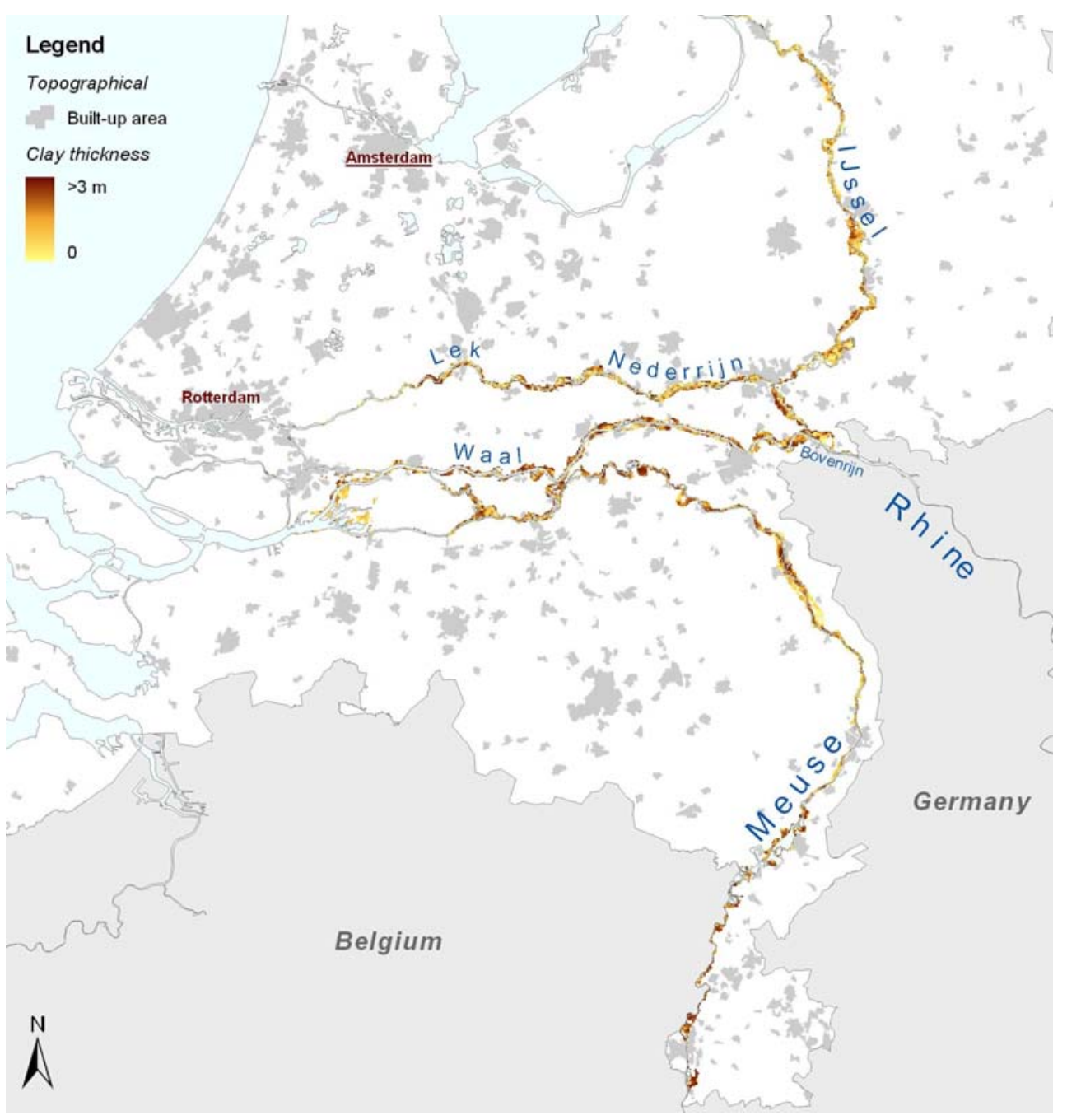

tives, we extended this ratio to the past. This puts our estimate of total clay extraction from the embanked floodplains at about 170 million $\mathrm{m}^{3}$ and the average rate of extraction at 1.1 million $\mathrm{m}^{3} /$ year. Post- 1850 extraction is bound to have included a share of pre-1850 clays. As this share is unknown, gross post-1850 deposition cannot be determined. It is probably in the order of tens of millions of cubic meter in addition to the net value of $0.2 \mathrm{~km}^{3}$.

\subsection{Current/large scale}

SEDIFLUX modeling of sedimentation along the Rhine distributaries results in a yearly deposited clay volume of $229 \times 10^{3} \mathrm{~m}^{3}$ (Table 2, Fig. 8). This is in accordance with estimates obtained from sediment traps (e.g., Middelkoop 1997; Middelkoop and Asselman 1998). For the Meuse, the sediment trap data analysis puts the average accumulation along the Meuse at $0.85 \mathrm{~mm} /$ year (see Table 2), which corresponds to a yearly deposited clay volume of $190 \times$ $10^{3} \mathrm{~m}^{3} /$ year. We are aware of the limitations of upscaling local values to a complete river branch, but as far we know, these are the only published contemporary accumulation estimates for this particular river. Furthermore, the average accumulation fits well with the estimated accumulation rates estimated along the River Rhine from modeling studies. The combined yearly depositional volume for the Rhine and Meuse floodplains is $419 \times 10^{3} \mathrm{~m}^{3}$. This corresponds to an average sediment accumulation rate of about $0.85 \mathrm{~mm} /$ year.

Minerals statistics for 1980-2006 show an overall decline of the extraction of clay for structural ceramics (Fig. 9). This trend was caused by changes in building practices. Up till the 1970s, most Dutch houses were built as brick constructions but since then, masonry became limited to the outer cavity leafs of external walls (as a facade): this basically substituted aggregates for clay as building raw material. On the decadal scale, production and consumption show a dependency on economy as evidenced, e.g., by dips during the recessions of the mid1980 s and early 2000 s. KNB forecasts a further decrease in the years to come. In view of these trends, we base an estimate of current structural ceramic clay consumption on 
Fig. 7 Upper panel Annual clay extraction from 1850 to 2005: 1 clay required for recorded brick production from 1938 to 1991 ; 2 clay extraction statistics (1980-2006; further detailed in Fig. 9); 3 an estimate of total clay production based on 1 and 2, see text for explanation; 4 estimated retrospective clay production (see text for explanation). Lower panel Cumulative clay extraction volumes from 1850 to $2006: 2,3,5$ the cumulative volumes corresponding to 2,3 , and 4 in the upper panel, respectively

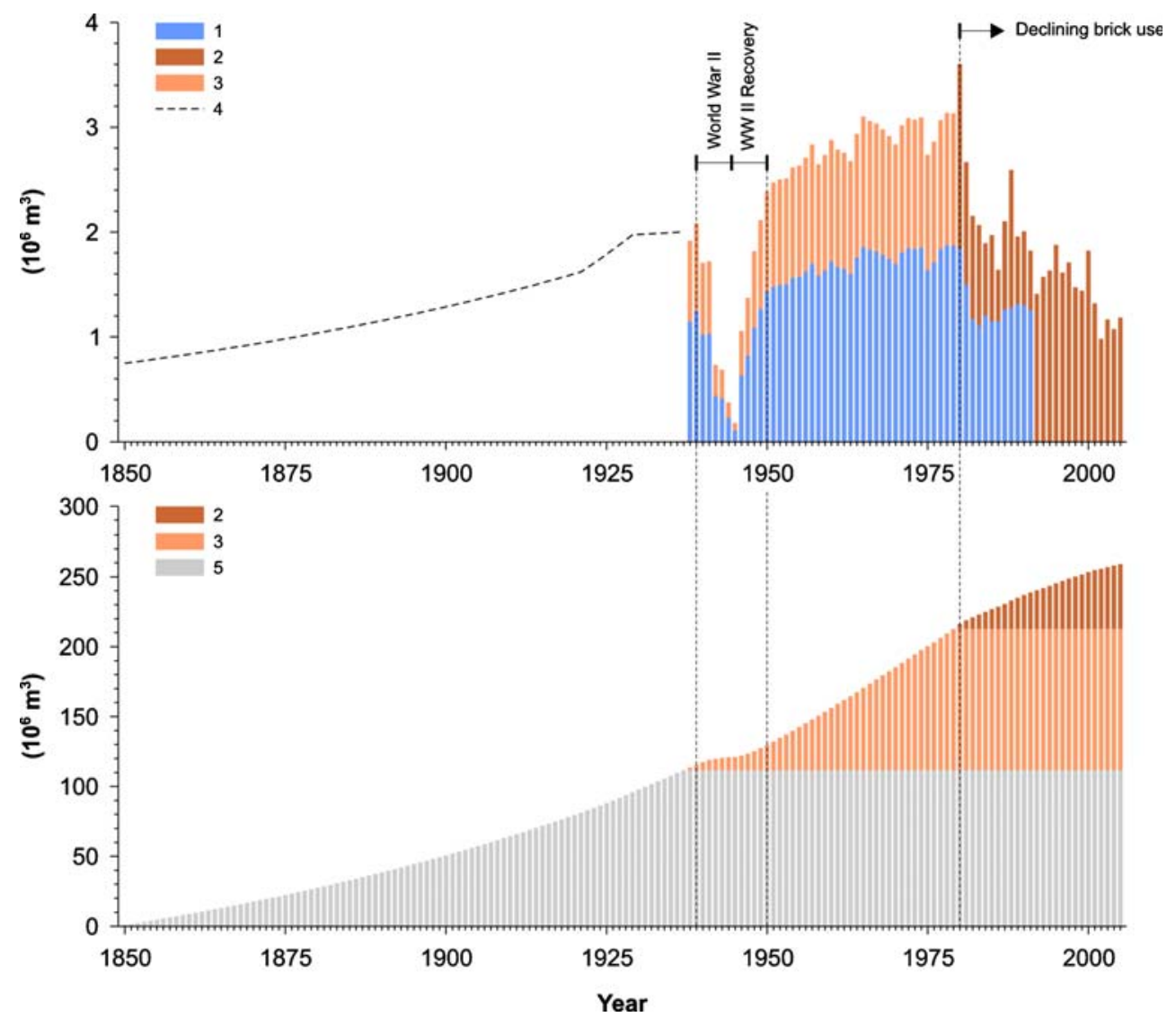

the figure for 2001 to 2006 . The average production in that period was $1.1 \pm 0.1$ million $\mathrm{m}^{3}$. The aforementioned two thirds of floodplain clay in the total supplies (Sigmond et al. 2001) puts the estimate of embanked floodplain clay extraction at 0.7 million $\mathrm{m}^{3} /$ year. A query among the largest brick producers in the Netherlands, conducted for verification purposes, yielded a production estimate of 1 to 1.5 million $\mathrm{m}^{3} /$ year. We attribute this figure being higher to the fact that not all of the producers could distinguish between embanked floodplain clays and fluvial clays in general.

\subsection{Current/site scale}

Based on radionuclide data, maximum sedimentation rates observed in floodplain depressions range from 6 to $18 \mathrm{~mm} /$ year (Middelkoop 2000; van den Berg and van Wijngaarden 2000; Table 3). Maximum rates obtained in SEDIFLUX models of the Rhine floodplains are about $9 \mathrm{~mm} /$ year (see Table 3; van der Perk et al. 2008; Straatsma et al. 2009). Based on these data, we assume that surface level lowering and/or increased sediment-trapping efficiency have the potential to raise sedimentation rates to about $1 \mathrm{~cm} /$ year locally. Extracting 0.7 million $\mathrm{m}^{3}$ of clay per year, from pits of $1.5 \mathrm{~m}$ in depth, requires the lowering of $0.5 \mathrm{~km}^{2}$ of floodplain surface area per year. At a sedimentation rate of $1 \mathrm{~cm} /$ year, replenishment will take about 150 years. This implies that about $75 \mathrm{~km}^{2}$ of floodplain would be required for sustainable clay extraction. This corresponds to about one sixth of the total floodplain surface area, which would suggest that sustainable clay extraction is indeed feasible. These values would be significantly lower if the observed shorter replenishment period of five to six decades (see above) is representative. There is, however, only one report of this phenomenon, and there are no verifiable sedimentation rates available at the appropriate time and spatial scales (decades and site, respectively).

\section{Analysis and discussion}

\subsection{Is clay a renewable resource?}

Our sediment budgeting effort allows for the following inferences:

- When considered on the long term (150 years), clay extraction from the embanked floodplain depositional environment has been sustainable. Cumulative resource depletion since $1850\left(\sim 170\right.$ million $\left.\mathrm{m}^{3}\right)$ amounted to less than the volume of clay that we estimate remained from the same period. The volume estimates in our 
Table 2 Current sedimentation rates for the Rhine distributaries (using the SEDIFLUX model) and for the Meuse (sediment trap data from Middelkoop and Asselman 1998)

\begin{tabular}{llcl}
\hline River/distributary & $\begin{array}{l}\text { Embanked floodplain surface } \\
\text { area }\left(\mathrm{km}^{2}\right)\end{array}$ & $\begin{array}{l}\text { Average accumulation rate } \\
(\mathrm{mm} / \mathrm{year})\end{array}$ & $\begin{array}{l}\text { Overall sedimentation rate } \\
\left(10^{3} \mathrm{~m}^{3} / \mathrm{year}\right)\end{array}$ \\
\hline Meuse & 223.5 & 0.85 & 190.0 \\
Waal and Bovenrijn & 91.5 & 1.21 & 110.7 \\
Nederrijn-Lek & 82.2 & 0.82 & 67.4 \\
IJssel & 93.3 & 0.54 & 50.4 \\
Total/average & 490.5 & 0.85 & 418.5 \\
\hline
\end{tabular}

See Fig. 6 for river and distributary names

balance are crude, especially that of cumulative clay use. Irrespective of that, data do allow us to establish that the clay resource volume increased while it was exploited, which would make clay a renewable resource
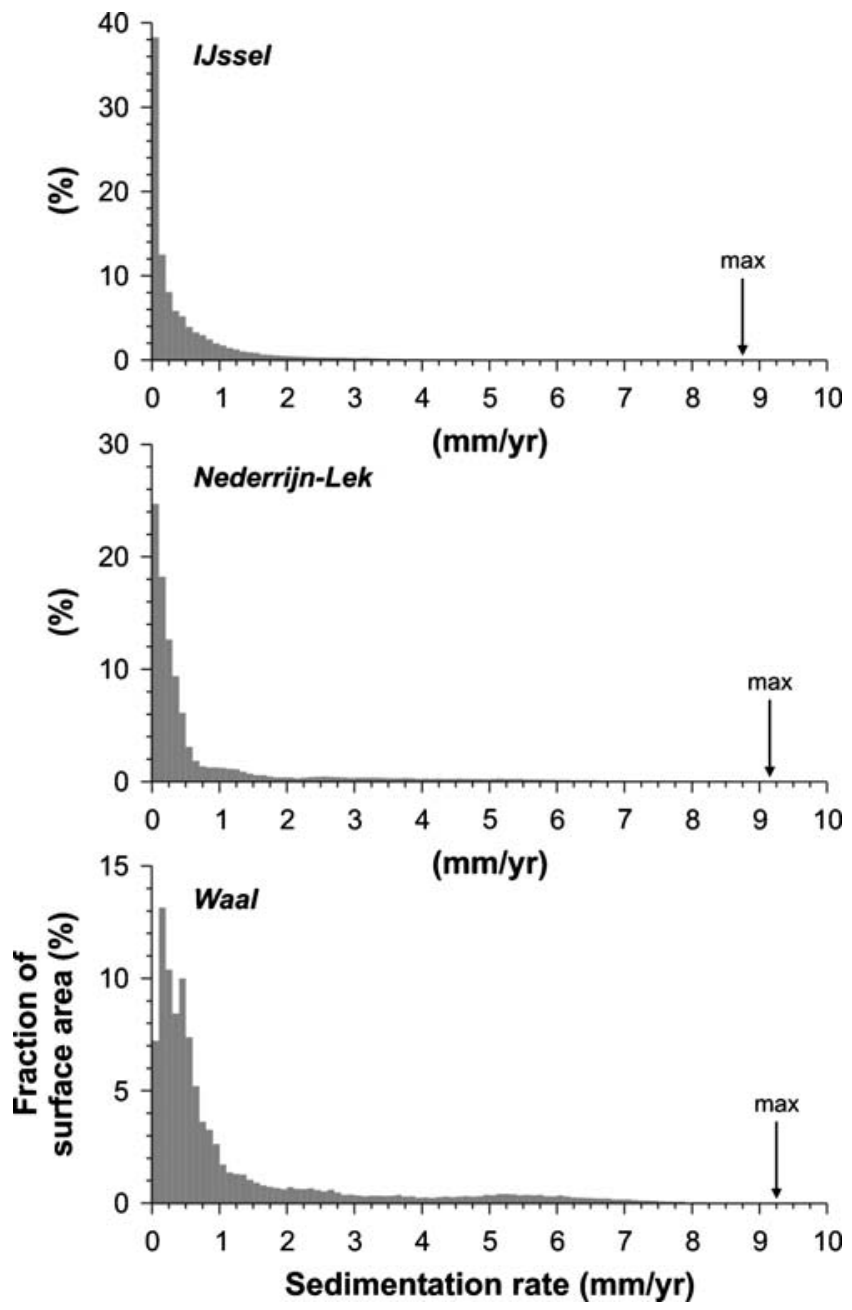

Fig. 8 Histograms of sedimentation rates modeled in the floodplains of the Rhine distributaries, expressed as cumulative share of the floodplain surface area (percent) per accumulation rate class $(0.1 \mathrm{~mm})$. Average and maximum values (the latter indicated with an arrow) are listed in Table 3 by any definition, at least on this particular timescale and in this particular setting.

- The current balance (deposition $\sim 0.4$ million $\mathrm{m}^{3} /$ year; extraction $\sim 0.7$ million $\mathrm{m}^{3} /$ year) seems to have shifted towards unsustainable. However, our figure for current deposition is probably an underestimate, as the morphological consequences of clay extraction are not fully represented in the underlying modeling. In addition to that, the sediment-trapping efficiency of individual clay extractions, which is not among the current objectives for site restoration, can be raised significantly. If sediment accumulation rates at clay sites can (be made to) attain the maximum of $\sim 1 \mathrm{~cm} /$ year, as currently and

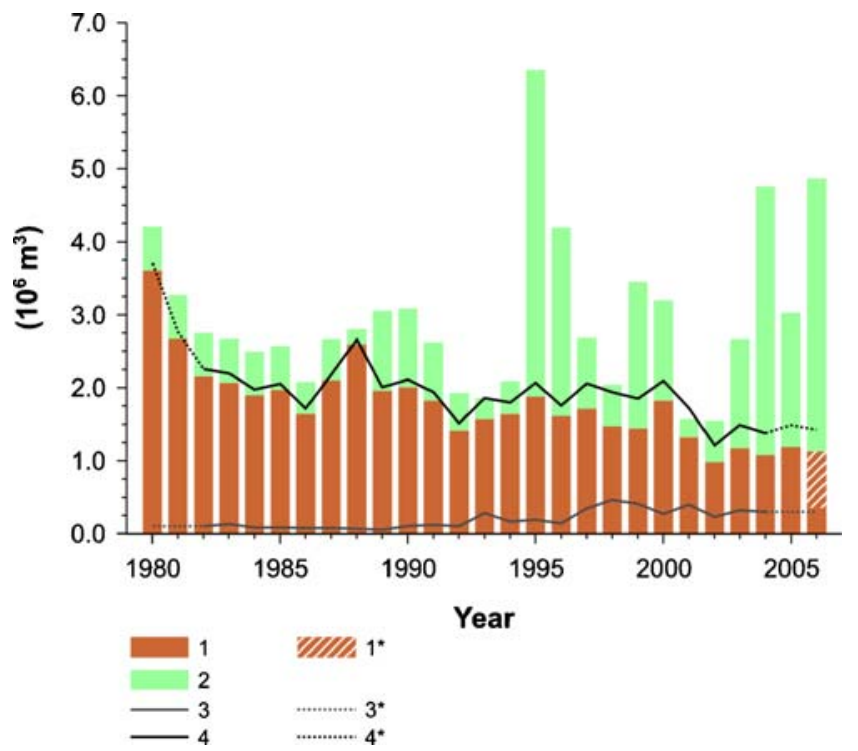

Fig. 9 Dutch clay production (1980-2006) for (1) structural ceramics (corresponds to 2 in Fig. 7) and (2) earthworks. Extraction for structural ceramics declines (see text) while net imports (3) rise somewhat. Consumption for structural ceramics manufacture (4) is approximated with $1+3$. Hatching $\left(1^{*}\right)$ represents an estimate that corrects for unreported production in one of the provinces in 2006; dotting $\left(3^{*}, 4^{*}\right)$ indicates estimated values for 3 and 4. Data: Van der Meulen et al. (2007a) and unpublished statistics from the mineral planning authorities (Provinces) 
Table 3 Maximum sedimentation rates as derived from geological/historical reconstructions and obtained from modeling

\begin{tabular}{llll}
\hline $\begin{array}{l}\text { River/ } \\
\text { distributary }\end{array}$ & $\begin{array}{l}\text { Embanked floodplain } \\
\text { surface area }\left(\mathrm{km}^{2}\right)\end{array}$ & $\begin{array}{l}\text { Maximum average accumulation } \\
\text { rate }(\mathrm{mm} / \mathrm{year})^{\mathrm{a}}\end{array}$ & $\begin{array}{l}\text { Modeled maximum accumulation } \\
\text { rate }(\mathrm{mm} / \text { year })^{\mathrm{b}}\end{array}$ \\
\hline Meuse & 223.5 & 12 & NA \\
Waal and Bovenrijn & 91.5 & 18 & 9 \\
Nederrijn-Lek & 82.2 & 6 & 9 \\
IJssel & 93.3 & 6 & 9 \\
Total/average & 490.5 & 11 & 9 \\
\hline
\end{tabular}

See Fig. 6 for river and distributary names

${ }^{\text {a }}$ Geological/historical reconstructions (see text)

${ }^{\mathrm{b}}$ Obtained from modeling (see text and Fig. 9)

$N A$ not available

historically observed in low-lying floodplain sections, then about one sixth of the embanked floodplain area would suffice for sustainable clay extraction. Based on this, we suggest that resource replenishment at the site level is a key objective for any future study into the renewability of clay. This applies to measurements of accumulation, as well as to the design of sediment traps.

Altogether, we argue that clay has been, probably is, and certainly can be managed as a renewable mineral resource. In that sense, the favorable comparison with other minerals worked in the Netherlands stands. A sediment-budget estimate for the Rhine reveals, for instance, that there is no net accumulation of sand and gravel in this system (Ten Brinke 2005), while the Dutch aggregates stocks are depleted at a rate of tens of millions of cubic meter per year (van der Meulen et al. 2005, 2007a). In fact, the amount of aggregate that is shipped towards the Netherlands over the Rhine (10-13 million $\mathrm{m}^{3} /$ year; van der Meulen et al. 2003) exceeds the amount of aggregate carried into the country by the same river system $\left(0.6\right.$ million $\mathrm{m}^{3} /$ year; Kleinhans 2002) by more than an order of magnitude. Dutch resources of chalk (a Cretaceous carbonate resource) and silica sand (a Mio-Pliocene quartz resource) are obviously not replenished at all. The only other mineral resource of which extraction and replenishment are in balance is shell valves.

\subsection{Analog: shell valves as renewable mineral resource}

Mollusk shell valves, especially from cockle (Cerastoderma edule), are used in applications such as path pavements, drains, animal fodder and thermal and moist isolation (van der Meulen 2004; van der Meulen et al. 2007a). Shells are obviously a renewable mineral resource and their extraction in the Netherlands is managed accordingly. The annually permitted volumes are limited to the average yearly growth increment of the exploitable shell stocks, which is derived periodically from biological shell production (cf. Beukema and Cadée 1999).

In the present context, it is of interest that shell extraction is not a matter of harvesting living material, but of dredging fossil shell-bearing deposits: either Holocene tidal channel deposits in the Waddenzee, where the extraction quota is set at $210,000 \mathrm{~m}^{3} /$ year, or Quaternary marine deposits of the Westerschelde estuary and its prodelta, where the quota is set at $80,000 \mathrm{~m}^{3} /$ year. As it is a sedimentary system rather than an ecosystem that is exploited, shell resources and their management bear relevance to our discussion on the renewability of clay deposits. Points of comparison are:

- Depletion and replenishment are defined and quantified on the scale of the depositional system that is exploited, rather than of a single deposit.

- Resource management is ultimately based on bulk deposition rates, which are periodically updated.

\subsection{Quality versus quantity}

In our assessment of sustainable clay extraction, we primarily took a quantitative, volumetric approach: clay quality is only addressed, to some extent, in our area selection criteria. These criteria were based on the facts that fireable clay is known to have been deposited on grasscovered floodplains, that peat formation is inhibitive, etc. However, it is not known how relevant quality parameters relate to a concept of clay site replenishment, especially if natural site restoration is undertaken, with different vegetation, and possibly wetter conditions (for a biogeochemical discussion of such areas, see Beumer 2009).

Modern production efficiency and quality requirements made the industry evermore "choosy" when it comes to their clay resources. Accordingly, assessing the quality of 
clay as ceramic material has come to be a rather specialized undertaking (e.g., van der Zwan 1990; van Wijck 1997), beyond the scope of the present study. On the other hand, successful experiments have been conducted to produce bricks from polluted dredging spoil (Claassen and van der Kooij 2003), and the structural ceramics industry historically worked clays with a much wider range of properties (textural, mineralogical, chemical; van der Meulen et al. 2007b). This suggests that there are possibilities beyond currently used clay resources, but we refrain from speculating on the quality aspects of sustainable clay resource management and suggest it is an important topic for future research.

The fact that post- 1850 clays can be identified by their pollution state raises another quality issue. While heavy metal pollution may inhibit their use in earthwork, firing immobilizes these contaminants to such an extent, that even the aforementioned experimental dredging-spoil bricks pass the mandatory leaching tests for stony building materials (Claassen and van der Kooij 2003; Anonymous 2007). Furthermore, the water quality of the Rhine and Meuse improved significantly since the early 1980s, and the heavy metal concentrations in the floodplain clays of that period decreased accordingly (Middelkoop 2000). This implies that using evermore recent clay for structural ceramics, which is implicit to the renewability concept, should not present a problem from an environmental point of view.

\section{Conclusions, recommendations, and perspectives}

We conclude that floodplain clay is a renewable resource, if managed accordingly. Other than for shell material, it is recommended that management should arrange for resource replenishment, instead of regulating resource exploitation (with quota). Whereas biological shell valve production is a given fact, than can be monitored but not influenced, clay deposition is severely affected by the morphology and layout of a depositional environment that is largely artificial. We demonstrated that the depositional system has sufficient carrying capacity: enough clay is or can be trapped to exploit sustainably. Further research is necessary, however, to evaluate the clay quality aspects of such concept.

Clay extraction is one of the main influences on the sediment budget of the embanked floodplains of the Netherlands: humans appear to operate on more or less geological scales. Other than for the resource management issue at hand, such notion is important in the wider context of river management. Both Rhine and Meuse are awaiting substantial landscaping and engineering works, aimed at increasing discharge capacity (Silva and Kok 1996; van der Meulen et al. 2006). Individual measures range from the removal of hydraulic obstacles such as groynes, to landsurface lowering or digging high-discharge channels in the embanked floodplains. The latter category, i.e., anything that involves significant digging: (1) affects the same deposits that are a resource to the structural ceramics industry, while resource sterilization should be avoided; and (2) is expected to result in higher sedimentation rates, just as clay extraction does locally.

Hence, we propose that the interests of the extractive industry and river managers could be served jointly with river management approaches that are based on sedimentbudget analyses. The more general inference is that managing rivers is just as much a matter of sediment management as it is of water management (cf. Brils 2002; Brils and De Deckere 2003; Owens 2005).

Acknowledgments This study was conducted under the umbrella of "Delta Evolution," a collaboration program between Deltares and Utrecht University. Funding was received from the Royal Dutch Association of Brick Producers (KNB), Deltares' R\&D program (project "Kust \& Zee-Sedimenthuishouding"), and BSIK-Delft Cluster project "Safety against Flooding" (4.30). The authors wish to thank Ewald van Hal, Leen de Jong, Gijs Sigmond, Gilles Erkens, Ad van der Spek, Sytze van Heteren, Marcel Bakker, and Joris Broers for discussions and suggestions. Two anonymous reviewers are kindly thanked for their helpful comments.

Disclaimer Although the authors adhere to its basic principles, clay resource data presented in this study do not formally comply with the Code for Reporting of Mineral Exploration Results, Mineral Resources and Mineral Reserves (Anonymous 2001). Our results are not to be used for the purpose of (a) informing investors or potential investors and their advisers or (b) satisfying regulatory requirements.

Open Access This article is distributed under the terms of the Creative Commons Attribution Noncommercial License which permits any noncommercial use, distribution, and reproduction in any medium, provided the original author(s) and source are credited.

\section{References}

Anonymous (2001) Code for reporting of mineral exploration results, mineral resources and mineral reserves (the Reporting Code). Institution of Mining and Metallurgy, London, European Federation of Geologists, Brussels, Geological Society of London, Institute of Geologists of Ireland, Dublin, pp 34

Anonymous (2007) Besluit Bodemkwaliteit: Decree of 22 November 2007 containing rules with respect to the quality of soil (Soil Quality Decree). Bulletin of Acts, Orders and Decrees of the Kingdom of the Netherlands, 2007 (469), pp 34

Beukema JJ, Cadée GC (1999) An estimate of the sustainable rate of shell extraction from the Dutch Wadden Sea. J Appl Ecol 36:49-58

Beumer V (2009) Winter flooding in Dutch stream valley floodplainsbiogeochemical effects and vegetation consequences. $\mathrm{Ph} . \mathrm{D}$. thesis Utrecht University, Utrecht, Netherlands, pp 143

Brils J (2002) The SedNet mission. J Soils Sediments 2(1):2-3

Brils J, De Deckere E (2003) SedNet-an evolving network aimed at sustainable sediment management. J Soils Sediments 3(3):127128 
Brundtland GH (1987) Our common future. Oxford University Press, Oxford, p 400

Claassen LMAE, van der Kooij LA (2003) Kennemer MopPraktijkproef van baggerslib tot baksteen (in Dutch, with English summary), Netherlands Centre for Soil Quality Management and Knowledge Transfer (SKB), Gouda, Netherlands, report SV-512, pp 26

Helmer W, Klink A, Overmars W, Litjens G (1992) Levende Rivieren (in Dutch). WWF-World Wide Fund for Nature, Zeist, p 28

Hesselink AW (2002) History makes a river-morphological changes and human interference in the river Rhine, The Netherlands. Ph.D. thesis Utrecht University, Neth Geogr Studies 292, pp 177

Kleinhans MG (2002) Sorting out sand and gravel; sediment transport and deposition in sand-gravel bed rivers. Ph.D. thesis Utrecht University, Neth Geogr Studies 293, 317 pp

Middelkoop H (1997) Embanked floodplains in the Netherlands. Ph.D. thesis Utrecht University, Neth Geogr Studies 224, pp 352

Middelkoop H (2000) Heavy-metal pollution of the river Rhine and Meuse floodplains in the Netherlands. Neth J Geosci 79(4):411428

Middelkoop H, Asselman NEM (1998) Spatial variability of floodplain sedimentation at the event scale in the Rhine-Meuse delta, The Netherlands. Earth Surf Process Landf 23:561-573

Middelkoop H, van der Perk M (1998) Modelling spatial patterns of overbank sedimentation on embanked floodplains. Geogr Ann 80A(2):95-109

Owens PN (2005) Conceptual models and budgets for sediment management at the river basin scale. J Soils Sediments 5(4):201212

Sigmond GJA, Hund JBA, van der Meulen MJ (2001) Ruimte voor Rijntakken: inventarisatie kleivoorkomens (in Dutch), Publicatiereeks Grondstoffen 2001/11. Road and Hydraulic Engineering Institute, Delft, p 24

Silva W, Kok M (1996) IVR Integrale Verkenning Rijntakken, Hoofdrapport-Een weegschaal voor rivierbeheer (in Dutch), IVR Report Nr. 1, RIZA, Arnhem, Netherlands, WL|Delft Hydraulics, Delft, Netherlands, pp 150

Statline (2008) http://statline.cbs.nl, public web portal of Statistics Netherlands, Heerlen, Netherland. Accessed on 25 Nov 2008 in order to retrieve historic production data of structural-ceramic products

Straatsma M, Schipper A, van der Perk M, van den Brink C, Middelkoop H, Leuven R (2009) Impact of value-driven scenarios on the geomorphology and ecology of lower Rhine floodplains under a changing climate. Landsc Urban Plan. doi:10.1016/j.landurbplan.2009.04.004

Ten Brinke W (2005) The Dutch Rhine, a restrained River. Veen Magazines BV, Diemen, p 228

Thonon I, Roberti JR, Middelkoop H, van der Perk M, Burrough PA (2005) In situ measurements of sediment settling characteristics in floodplains using a LISST-ST. Earth Surf Process Landf 30 (10):1327-1343
Thonon I, De Jong K, van der Perk M, Middelkoop H (2007) Modelling floodplain sedimentation using particle tracking. Hydrol Process 21(11):1402-1412

van den Berg GA, van Wijngaarden M (2000) Sedimentatie langs de Grensmaas (in Dutch). RIZA rapport 2000.046, ISBN 9036953456, pp 62

van der Meulen MJ (2004) Evaluatie Landelijke Beleidsnota Schelpenwinning (in Dutch). Road and Hydraulic Engineering Institute, Delft, p 28

van der Meulen MJ (2005) Sustainable mineral development: possibilities and pitfalls illustrated by the rise and fall of Dutch mineral planning guidance. In: Marker BR, Petterson MG, McEvoy F, Stephenson MH (eds) Sustainable minerals operations in the developing world. Geol Soc Spec Publ 250:225-232

van der Meulen MJ, Koopmans TPF, Pietersen HS (2003) Construction raw materials policy and supply practices in northwestern Europe. In: Elsen J, Degryse P (eds) Industrial minerals-resources, characteristics and applications. Aardk Mededel 13:19-30

van der Meulen MJ, van Gessel SF, Veldkamp JG (2005) Aggregate resources in the Netherlands. Neth J Geosci 84(3):379-387

van der Meulen MJ, Rijnveld M, Gerrits LM, Joziasse J, van Heijst MWIM, Gruijters SHLL (2006) Handling sediments in Dutch river management: the planning stage of the Maaswerken river widening project. J Soils Sediments 6(3):163-172

van der Meulen MJ, Broers JW, Hakstege AL, Pietersen HS, van Heijst MWIM, Koopmans TPF (2007a) Surface mineral resources. In: Wong TE, Batjes DAJ, De Jager J (eds) Geology of the Netherlands. Royal Netherlands Academy of Arts and Sciences (KNAW), Amsterdam, pp 317-333

van der Meulen MJ, Maljers D, van Gessel SF, Gruijters SHLL (2007b) Clay resources in the Netherlands. Neth J Geosci 86(2):117-130

van der Meulen MJ, van der Spek AJF, De Lange G, Gruijters SHLL, van Gessel SF, Nguyen BL, Maljers D, Schokker J, Mulder JPM, van der Krogt RAA (2007c) Regional sediment deficits in the Dutch lowlands: implications for long-term land-use options. J Soils Sediments 7(1):9-16

van der Perk M, Straatsma M, Middelkoop H, van den Brink NGM (2008) Quantification of fine sediment retention in the Rhine delta using a two-dimensional floodplain sedimentation model. Geophys Res Abstr 10, EGU2008-A-05566

van der Zwan JT (1990) Inventarisatie van kleivoorkomens in Nederland geschikt voor de grof-keramische industrie en de dijkbouw. Road and Hydraulic Engineering Institute, Delft, Netherlands, report TW-R-89-4, pp 36

van Wijck JH (1997) Grofkeramische kleien in Nederland (in Dutch). Klei Glas Keram 18(10):14-17

van Zanden JL (1997) The economic history of the Netherlands 19141995: a small open economy in the long twentieth century. Routledge, London, p 220. ISBN 978-0-203-98492-5

Wagner H, Tiess G, Nielsen K, Solar S, Hamor T, Ike P, Vervoort A, Espi JA, Agiountantis Z, Koziol W, Bauer V (2004) Minerals planning policies and supply practices in Europe. Montanuniversität Leoben, Leoben, p 355 